Research Article / Araştırma Makalesi

\title{
A COMPARATIVE ANALYSIS ON GRADUATE THESES IN THE FIELD OF PUBLIC RELATIONS AND ADVERTISING IN TURKEY*
}

\author{
Assoc. Prof. Mikail BATU \\ Ege University, Faculty of Communication, İzmir, Turkey, (mikail.batu@ege.edu.tr)
}

Phd. Yeliz YAPICIOĞLU AYAZ $\mathbb{D}$

Ege University, Faculty of Communication, İzmir, Turkey, (yeliz.yapicioglu@gmail.com)

\begin{abstract}
Nowadays, scientific studies at academic level in public relations and advertising are carried out in universities, and the results of the studies are evaluated by academicians and the researchers gains some titles. After graduation, someone becomes a scientist by studying Master of Science in the same field or certain fields and gains the highest level of academic title by studying for doctorate. At this point, theses in the public relations and advertising areas produced under institutes are written to give new perspectives and indicate scientific and tangible facts.The purpose of this study is to determine the main subjects in graduate theses written in public relations and advertising areas. The reason for the study is that there is no comprehensive and comparative study on theses in the fields of public relations and advertising in literature in Turkey. In the study, the bibliometric characteristics of the theses of public relations and advertising studies on www.tez.yok.gov.tr are analyzed. The sample size of this study includes 504 approved graduate theses published between the years 2007 and 2017 in these fields. As a result, it is seen that most of the theses in public relations were written on the subjects such as public relations, public relations discipline, public relations education, etc. The least number of theses were found to be written on the subjects such as business, international business and SME. In the field of advertising, it can be said that most of the theses were written on the subjects such as advertising tools, advertising control, advertising evaluation, etc. The least number of theses in advertising were found to be written on the subjects including brand, product and property.
\end{abstract}

Keywords: Public Relations, Advertising, Graduate Theses, Qualitative Study, Content Analysis.

\section{TÜRKIYYE'DE HALKLA İLIŞKILER VE REKLAMCILIK ALANLARINDA YAZILMIŞ LISANSÜSTÜ TEZLERINE YÖNELIK KARŞILAŞTIRMALI BİR ANALIZZ}

\begin{abstract}
ÖZET
Günümüzde, halkla ilişkiler ve reklamcılık alanlarında akademik düzeyde bilimsel çalışmalar üniversitelerde yapılmakta ve çalışma sonuçları öğretim üyeleri tarafindan değerlendirilerek çalışma sahipleri bazı dereceler kazanmaktadır. Mezun olduktan sonra aynı alanda veya belli alanlarda yüksek lisans yapılarak bilim uzmanı olunmakta, doktora yapılarak da en yüksek seviyeli akademik derece alınmaktadır. Bu noktada enstitülere bağlı olarak üretilen halkla ilişsiler ve reklamcılık ile ilgili tezler,
\end{abstract}

\footnotetext{
* This study was improved from an oral presentation communique at the 1st International Conference on Critical Debates in Social Sciences (ICCDSS) on the dates of October 5 and 7, 2018.
}

www.ijmeb.org ISSN:2147-9208 E-ISSN:2147-9194

http://dx.doi.org/10.17130/ijmeb.785223

Received: 25.08.2020, Accepted: 11.01.2021

600 
alana yeni bakış açısı kazandırmak, bilimsel ve somut gerçekleri ortaya koyabilmek için yazılmaktadır. Bu çalışma, Türkiye'deki üniversitelerde halkla ilişskiler ve reklamcılık alanlarında yazılmış lisansüstï tezlerdeki eğilimleri ortaya koymayı amaçlamaktadır. Çalışmanın yapılma nedeni halkla ilişkiler ve reklamcılık alanlarında Türkiye'de tezlere ilişkin literatürde kapsamlı ve kıyaslayıcı bir çalışmanın bulunmamasıdır. Çalışmada www.tez.yok.gov.tr sayfasında yayınlanan halkla ilişkiler ve reklamcillk alanlarındaki tezler analiz edilmektedir. Çalışmanın örneklemi 2007-2017 yılları arasında, bu alanlarda yayınlanmış 504 izinli lisansüstü tezi kapsamaktadır. Sonuç olarak, halkla ilişkiler alanında tezlerin en çok "halkla ilişkiler, halkla ilişkiler disiplini, halkla ilişkiler eğitimi vb. üzerine yazıldığı görülmüştür. Halkla iliş̧kiler alanında en az işletme, uluslararası işletme, kobi vb. konularında tezlerin yazılmış olduğu saptanmıştır. Reklamcılık alanında ise en çok reklam araçları, reklam denetim, reklam değerlendirme, vb. üzerinde durulduğu görülmü̈şür. Reklamcılık alanında ise tezler en az marka, ürün, mal konuları üzerine yazılmiştır.

Anahtar Kelimeler: Halkla İlişkiler, Reklamcılık, Lisansüstü Tezler, Nitel Çalışma, İ̧erik Analizi.

\section{Introduction}

According to Hume, all sciences are related to human beings at different rates. Mathematics, philosophy of nature, natural religion like science or disciplines must also be linked to human nature (Çıvgın, 2013:34). This relationship is understandable through a detailed examination of observations and experiences. According to Popper, the scientific theory can be inspired by what was said earlier (Akgün, 2015:61). In each study, scientific knowledge is firstly linked with the subject to be examined and assumptions at an abstract level are transformed into concrete results (Yaşın et al., 2017:456-457). The scientific research and communication process can vary over the course of time, it is significant to examine what these differences are what they mean in scientific and social terms (Uçak \& Al, 2009:2). For instance, a detailed examination of the graduate theses in a specific field is important in determining the main subjects, tendencies and changing application areas in the relevant field (Dogan, 2017:931). Today, a major part of scientific research consists of graduate theses. Graduate theses have an important archive function in which the experience is transferred to future studies. A student in the graduate program should write his/her scientific research in accordance with the rules adopted by the relevant institution_and defend his/her entire study verbally against the previously determined jury (Benligiray, 2012:27).

Several master's and doctoral theses are written every year in different fields (Çetin et al., 2016:244). In addition, research and analysis on graduate theses and research methods are carried out in the disciplines, which types of materials are used in these disciplines (Uçak, 2009:1), which outcomes are totally achieved and what kind of new research is needed (Şimşek et al., 2008:441), which sources are compiled and discussed, and to what extent these resources cover the current debates (Çetin et al., 2016:244) are tried to be explained. There are theses written with different purpose, methods and contents in the field of Public Relations. However, why and how these theses were written are as important as their writing. Okay \& Okay (2008) examined the graduate theses on public relations written at Turkish Universities between 19842007. In 673 theses, the universities where the theses were written, language, sex and whether the thesis supervisor was related to public relations were investigated. It has been concluded that the contribution of the theses to the development of public relations, especially to the 
formation of theories, was not much. There was not any thesis on public relations theory in the theses analyzed was noteworthy. Çetin et al. (2016) evaluated the theses in the field of public relations in Turkey. In their studies, the types of sources of doctoral theses written in 2015 in the field of public relations were investigated. As a result, it was seen that the theses written in Turkey followed the developments in the world, although not very closely. However, it was determined that the contents of the theses were not related to current issues and events. Çilingir (2017) conducted a study on graduate theses to obtain data about the use of content analysis method in theses in the field of communication. In this study, 33 master theses and 31 doctoral theses between 1996-2015 were examined. In the study, it was determined that content analysis was used in the theses written in the field of communication, especially in the last 10 years. Yaşin et al. (2017) conducted a research on doctoral theses written in 2016 in the field of public relations to compare academic studies in Turkey and The United States of America (USA). In the study, the answer to the following question was sought. Are there any differences in terms of resources used in citations of doctoral theses written in the field of public relations in Turkey and the USA? Content analysis was used to evaluate the data. As a result, it was determined that textbook was mostly used in the theses in Turkey and scientific papers were mostly used in the theses in USA. References to the symposium papers and scientific reports published in both countries have been limited. The scientific sources used in Turkey were found to be more up to date than the USA. It has been understood that scientific standards of the sources used in the USA are more specific and some unscientific sources were used in Turkey. Batu \& Ayaz (2018) conducted a review of graduate theses in order to determine how scientific writing about social media was. In the study, 348 graduate theses were reviewed with content analysis. It was seen that master's theses about this subject were mostly written in the fields of public relations, business and informatics, and for doctoral theses the first three programs were public relations and publicity, business and informatics, respectively. Becan (2019) conducted a bibliometric analysis on graduate theses in his study on dominant and critical approaches in advertising literature. In this study, graduate theses in the field of advertising in Turkey between 2008-2018 were examined. In the study, bibliometric analysis was made on numerical changes by years, basic research topics, basic approaches and research methods/research techniques. According to the results of the research, the number of theses and interdisciplinary feature has increased significantly in recent years. Issues in advertising have changed according to environmental developments. In addition, in the theses written in the field of advertising, it was seen that the dominant approach was mostly adopted and qualitative researches were used. Polat (2020) examined 11 doctoral theses in his doctoral theses in the field of public relations, where he investigated the phenomenon of new media. In the study, in which content analysis was made, codings in 13 different titles were carried out. It has been concluded that the theses were mostly written in Istanbul, the number of theses dealing with the relation between new media and public relations was not sufficient, and the institutions did not use the new media effectively.

The first Master's thesis in public relations in Turkey was written at Istanbul University in 1982 on Public Relations at a mental hospital. The first doctoral thesis was written in 1990 at Istanbul University on "Public Relations in Theory and Practice". There are graduate programs on public relations and advertising in 30 universities in Turkey. Graduate programs are called Public Relations in 7 Universities, Public Relations and Publicity in 16 universities, Public Relations and Advertising in 3 universities, and Advertising in 6 universities are used. In 
doctoral programs, the following program names are used: Public Relations and Publicity in 9 Universities, Public Relations and Advertising in 2 universities, and Advertising in 2 universities. These programs are still active in the following universities: Adnan Menderes University, Akdeniz University, Anadolu University, Ankara University, Atılım University, Atatürk University, Bahcesehir University, Baskent University, Dicle University, Ege University, Erciyes University, Istanbul University, Gazi University, Galatasaray University, Giresun University, Gümüshane University, Istanbul Aydin University, Istanbul Bilgi University, Istanbul Gelisim University, Istanbul Commerce University, Istanbul Medipol University, Izmir University of Economics, Kadir Has University, Istanbul Technical University, Marmara University, Sakarya University, Selçuk University, Uşak University and Yeditepe University.

The first master's thesis in advertising in Turkey was titled: "Advertising Agencies in Turkey" at Istanbul University in 1985. The first doctoral thesis was written on "Radio Advertising in Turkey" at Atatürk University in 1982. Within the scope of the study, the theses in the National Thesis Center were examined between the years 2007 and 2017. In this period, 229 master's theses were written in the advertising field; 197 were open access and 32 were not open access. It is also observed that 69 theses were produced in doctoral programs. 54 of them were open access and 15 were not open access.

\section{Methodology}

In this study, the content analysis was used. Content analysis, which can be seen as both a quantitative and qualitative technique, refers to all of the techniques that are applied to different types of texts in the framework of certain methods (Bilgin, 2004:1). The main purpose of content analysis is to identify concepts and relationships that can accurately and appropriately explain the previous data. The data should be conceptualized by the researcher and prepared in a comprehensible manner according to the information which is obtained in this context and themes should be formed within this framework (Yıldırım \& Şimşek, 2011:227). Aziz (2008:124) discussed 7 important elements of content analysis including data collection, unitizing, sampling, recording elements, analysis, inference, and reporting of the study. Yıldırım \& Şimşek (2011) indicate that content analysis can be done in four categories, including the coding of the data, finding the themes, editing the codes and themes, and defining and interpreting the findings. To perform content analysis in this study, open access graduate theses in the field of public relations and advertising have been accessed via the web site www. yok.gov.tr. Categories were created and data was analyzed by examining the theses published in these fields.

\subsection{The Purpose of the Study}

This study analyzes and compares the bibliometric properties of graduate theses in the fields of public relations and advertising between the years 2007 and 2017. The purpose of the study is to determine the main subjects in graduate theses written in public relations and advertising at the universities in Turkey. 


\subsection{Universe, Sampling and Limitations of the Study}

The universe of the research includes theses with the keywords of public relations and advertising at www.tez.yok.gov.tr (website address of the National Thesis Center). The sample of the study includes 504 graduate theses in the fields of public relations and advertising between the years 2007 and 2017 (the last 10 years were taken when the study was started) at the National Thesis Center.

In the National Thesis Center, there are 520 masters and 110 doctoral theses in public relations. Between the years 2007 and 2017, there were 226 masters' theses in public relations, from this total, 201 are open access and 25 are not open access. In terms of doctoral theses there are 62 in public relations. From this total, 52 of them are open access and 10 of them are not open access.

Table 1: Public Relations

\begin{tabular}{llcccc}
\hline & & MA & PhD & Total \\
\hline \multirow{3}{*}{ The Entire Database } & Open Access & 287 & 68 & \\
\cline { 2 - 5 } & Non- Open Access & 233 & 42 & \\
\cline { 2 - 5 } Between the years 2007 and 2017 & Total & 520 & 110 & 630 \\
\hline & Open Access & 201 & 52 & \\
\cline { 2 - 5 } & Non-Open Access & 25 & 10 & \\
\cline { 2 - 5 } & Total & 226 & 62 & 288 \\
\hline
\end{tabular}

When the "advertising" keyword is entered into the National Thesis Center, there are 574 master theses identified, the number of open access master's theses is 413 and the number of non-open access master's theses is 161 . When the doctoral theses are examined, there are totally 104 theses, 74 of them are open access and 30 of them are not open access. In total, the graduate and doctoral theses with open access and non-open access are 678. Between the years 2007 and 2017, 229 master theses were written on advertising. Out of the 229 theses, 32 of them are not open access and 197 of them are open access. Considering the same years, there are 69 doctoral theses, 54 of them are open access and 15 of them are not open access.

The limitations of the research are the consideration of the theses published between the years 2007 and 2017, and the evaluation of only open access thesis.

Table 2: Advertising

\begin{tabular}{llccc}
\hline & & MA & PhD & Total \\
\hline The Entire Database & Open Access & 413 & 74 & \\
\cline { 2 - 5 } & Non-Open Access & 161 & 30 & \\
\cline { 2 - 5 } & Total & 574 & 104 & 678 \\
\hline \multirow{2}{*}{\begin{tabular}{l} 
Between the Years 2007 and \\
\cline { 2 - 5 }
\end{tabular}} & Open Access & 197 & 54 & \\
\cline { 2 - 5 } & Non-Open Access & 32 & 15 & \\
\cline { 2 - 5 } & Total & 229 & 69 & 298 \\
\hline
\end{tabular}




\subsection{Research Questions}

In respect of those theses written in public relations and advertising between the years 2007 and 2017 at the National Thesis Center, the following research questions were posed:

1.1.1 How many theses were masters and how many were doctoral theses?

1.1.2 What are the permitting conditions of the theses?

1.1.3 In which languages are the theses published?

1.1.4 What are the sex percentage rates of authors?

1.1.5 What is the range of pages of the theses?

1.1.6 What is the rate of supervisors' titles in the theses?

1.1.7 What are the research methods and techniques used in the theses?

1.1.8 In which universities were the theses published?

1.1.9 In which programs of the universities were the theses published?

1.1.10 What is the publication density of the theses by years?

\section{Findings}

Within the scope of the study, the theses at the National Thesis Center in Turkey between the years 2007 and 2017 were examined. The results are presented below together with the tables and explanations.

\section{Table 3: Thesis Program}

\begin{tabular}{lcc}
\hline Type of Thesis & Public Relations & Advertising \\
\hline $\mathrm{MA}$ & 226 & 229 \\
\hline $\mathrm{PhD}$ & 62 & 69 \\
\hline Total & 288 & 298 \\
\hline
\end{tabular}

Between the years 2007 and 2017, 288 theses were published in the field of public relations in Turkey, 266 of them were master's and 62 were doctoral theses. In the field of advertising, on the other hand, 298 theses were published totally, 229 of them were masters and 69 of them were doctoral theses.

Table 4: Access Type of the Thesis

\begin{tabular}{lcccccccc}
\hline & \multicolumn{4}{c}{ Public Relations } & \multicolumn{4}{c}{ Advertising } \\
\hline Access Type & MA & Percentage & DR & Percentage & GR & Percentage & DR & Percentage \\
\hline Open Access & 201 & $88.93 \%$ & 52 & $83.87 \%$ & 197 & $86.02 \%$ & 54 & $78.26 \%$ \\
\hline Not Open Access & 25 & $11.06 \%$ & 10 & $16.12 \%$ & 32 & $13.97 \%$ & 15 & $21.73 \%$ \\
\hline Total & 226 & $99.99 \%$ & 62 & $99.99 \%$ & 229 & $99.99 \%$ & 69 & $99.99 \%$ \\
\hline
\end{tabular}


In the field of public relations, it is observed that $88.93 \%$ of the master's theses in Turkey are open access and $11.06 \%$ of them are not open access; $83.87 \%$ of the doctoral theses are open access and $16.12 \%$ of them are not open access. In the field of advertising, it is seen that $86.02 \%$ of the master's theses are open access and $13.97 \%$ of them are not open access and $78.26 \%$ of the doctoral theses are open access and $21.73 \%$ of them are not open access.

Table 5: Thesis Language

\begin{tabular}{lcccccccc}
\hline & \multicolumn{4}{c}{ Public Relations } & \multicolumn{3}{c}{ Advertising } \\
\hline Language & MA & Percentage & PhD & Percentage & MA & Percentage & PhD & Percentage \\
\hline Turkish & 200 & $99.50 \%$ & 64 & $98.07 \%$ & 173 & $87.81 \%$ & 46 & $85.18 \%$ \\
\hline English & 1 & $0.49 \%$ & 1 & $1.92 \%$ & 21 & $10.65 \%$ & 6 & $11.11 \%$ \\
\hline German & - & - & - & - & 2 & $1.01 \%$ & 1 & $1.85 \%$ \\
\hline French & - & - & - & - & 1 & $0.50 \%$ & 1 & $1.85 \%$ \\
\hline Total & 201 & $99.9 \% 9$ & 52 & $99.99 \%$ & 197 & $99.97 \%$ & 54 & $99.99 \%$ \\
\hline
\end{tabular}

While $99.50 \%$ of the master's theses written in public relations in Turkey are in Turkish and $0.49 \%$ of them are in English, $98.07 \%$ of the doctoral theses are in Turkish and $1.92 \%$ of them are in English. $87.81 \%$ of the master's theses written in the field of advertising are in Turkish, $10.65 \%$ of them are in English, 1.01\% of them are in German and $0.50 \%$ of them are in French. $85.18 \%$ of doctoral theses are in Turkish, $11.11 \%$ of them are in English, 1.85\% of them are in German, and $1.85 \%$ of them are in French. Therefore, it is observed that the thesis languages of master's and doctoral programs are highly (mostly) in Turkish.

Table 6: Sex of Authors

\begin{tabular}{lcccccccc}
\hline & \multicolumn{4}{c}{ Public Relations } & \multicolumn{3}{c}{ Advertising } \\
\hline Sex & MA & Percentage & PhD & Percentage & MA & Percentage & PhD & Percentage \\
\hline Female & 118 & $58.70 \%$ & 32 & $61.53 \%$ & 117 & $59.39 \%$ & 21 & $38.88 \%$ \\
\hline Male & 83 & $41.29 \%$ & 20 & $38.46 \%$ & 80 & $40.60 \%$ & 33 & $61.11 \%$ \\
\hline Total & 201 & $99.99 \%$ & 52 & $99.99 \%$ & 197 & $99.99 \%$ & 54 & $99.99 \%$ \\
\hline
\end{tabular}

It is observed that $58.70 \%$ of the master's theses in public relations in Turkey are written by women, and $41.29 \%$ of them are written by men. $61.53 \%$ of the doctoral theses are written by women, and $38.46 \%$ of them are written by men. When we look at the sex status of the authors of master's theses in the field of advertising, it is observed that $59.39 \%$ of the authors of graduate theses are women, and $40.60 \%$ are men and $38.88 \%$ of the authors of doctoral theses are women and $61.11 \%$ are men. It is determined that a higher percentage the master's and doctoral theses in the field of public relations are written by women than men. It is also indicated that women are higher in number in the graduate theses written in the field of advertising while men are higher in number in the doctoral theses. 
Table 7: Page Numbers of Thesis

\begin{tabular}{lcccccccc}
\hline & \multicolumn{4}{c}{ Public Relations } & \multicolumn{4}{c}{ Advertising } \\
\hline Page Number & MA & Percentage & PhD & Percentage & MA & Percentage & PhD & Percentage \\
\hline $50-100$ & 23 & $11.44 \%$ & - & - & 54 & $27.41 \%$ & - & - \\
\hline $101-150$ & 82 & $40.79 \%$ & 2 & $3.84 \%$ & 78 & $39.59 \%$ & 4 & $7.40 \%$ \\
\hline $151-200$ & 50 & $24.87 \%$ & 5 & $9.62 \%$ & 35 & $17.76 \%$ & 11 & $20.37 \%$ \\
\hline $201-250$ & 26 & $12.93 \%$ & 7 & $13.46 \%$ & 23 & $11.67 \%$ & 12 & $22.22 \%$ \\
\hline $251-300$ & 12 & $5.97 \%$ & 12 & $23.07 \%$ & 4 & $2.03 \%$ & 6 & $11.11 \%$ \\
\hline $301-350$ & 8 & $3.98 \%$ & 11 & $21.15 \%$ & 2 & $1.01 \%$ & 5 & $9.25 \%$ \\
\hline $351-400$ & - & - & 3 & $5.76 \%$ & - & - & 4 & $7.40 \%$ \\
\hline $401-450$ & - & - & 8 & $15.38 \%$ & 1 & $0.50 \%$ & 2 & $3.70 \%$ \\
\hline $451-500$ & - & - & 1 & $1.92 \%$ & - & - & 5 & $9.25 \%$ \\
\hline 500 and more & - & - & 3 & $5.76 \%$ & - & - & 1 & $1.85 \%$ \\
\hline Total & 201 & $99.98 \%$ & 52 & $99.96 \%$ & 197 & $99.97 \%$ & 54 & $92.55 \%$ \\
\hline
\end{tabular}

It is seen that $40.79 \%$ of the master's theses written in the field of public relations in Turkey are prepared within the range of 101-150 pages, while $23.07 \%$ of the doctoral theses are prepared within the range of 251-300 pages. It is also determined that $39.59 \%$ of the master's theses in the advertising field are written within the range of 101-150 pages while $22.22 \%$ of the doctoral theses were written within the range of 201-250 pages.

Table 8: Titles of the Thesis Supervisors

\section{Public Relations}

Advertising

\begin{tabular}{lcccccccc}
\hline Title & MA & Percentage & PhD & Percentage & MA & Percentage & PhD & Percentage \\
\hline Prof. & 53 & $26.36 \%$ & 29 & $55.76 \%$ & 60 & $30.45 \%$ & 41 & $75.92 \%$ \\
\hline Assoc. Prof. & 65 & $32.33 \%$ & 20 & $38.46 \%$ & 59 & $29.94 \%$ & 8 & $14.81 \%$ \\
\hline Assist. Prof. & 83 & $41.29 \%$ & 3 & $5.76 \%$ & 74 & $37.56 \%$ & 2 & $3.70 \%$ \\
\hline Lecturer & - & - & - & - & 2 & $1.01 \%$ & 3 & $5.55 \%$ \\
\hline PhD & - & - & - & - & 2 & $1.01 \%$ & - & - \\
\hline Total & 201 & $99.98 \%$ & 52 & $99.98 \%$ & 197 & $99.97 \%$ & 54 & $99.98 \%$ \\
\hline
\end{tabular}

It is seen that $41.29 \%$ of the faculty members with the title of Assistant Professor are mostly supervisors of the master's theses in the field of public relations, and $32.33 \%$ of the faculty members with the title of Associate Professor are the second with the highest number of being supervisors. It is observed that in the doctoral theses, $75.92 \%$ of the Professors are mostly the supervisors and $14.81 \%$ of the faculty members with the title of Associate Professors are supervisors. In both fields, it is observed that the master's theses were mostly supervised by Assistant Professors while doctoral theses were mostly supervised by Professors. This indicates that the degree of the titles may affect the supervisors in the programs. 
Table 9: Research Methods and Techniques Used in Theses

\begin{tabular}{|c|c|c|c|c|c|c|c|c|}
\hline \multicolumn{5}{|c|}{ Public Relations } & \multicolumn{4}{|c|}{ Advertising } \\
\hline Method & MA & Percentage & PhD & Percentage & MA & Percentage & PhD & Percentage \\
\hline Survey & 93 & $46.26 \%$ & 28 & $53.84 \%$ & 57 & $28.93 \%$ & 18 & $33.33 \%$ \\
\hline Semiotic Analysis & - & - & - & - & 39 & $19.79 \%$ & 7 & $12.96 \%$ \\
\hline In-depth Interview & 26 & $12.93 \%$ & 4 & $7.69 \%$ & 10 & $5.07 \%$ & 5 & $9.25 \%$ \\
\hline Focus Group Study & - & - & - & - & 4 & $2.03 \%$ & - & - \\
\hline Content Analysis & 19 & $9.45 \%$ & 4 & $7.69 \%$ & 18 & $9.13 \%$ & 4 & $7.40 \%$ \\
\hline Film Analysis & - & - & - & - & 1 & $0.50 \%$ & - & - \\
\hline $\begin{array}{l}\text { Mathematical } \\
\text { Programming/ } \\
\text { Analysis }\end{array}$ & - & - & - & - & 1 & $0.50 \%$ & 1 & $1.85 \%$ \\
\hline $\begin{array}{l}\text { Econometric } \\
\text { Analysis }\end{array}$ & - & - & & & - & - & 1 & $1.85 \%$ \\
\hline $\begin{array}{l}\text { Comparative } \\
\text { Analysis }\end{array}$ & 2 & $0.99 \%$ & & & 3 & $1.52 \%$ & 3 & $5.55 \%$ \\
\hline Case Study Analysis & 6 & $2.98 \%$ & 2 & $3.84 \%$ & 2 & $1.01 \%$ & 2 & $3.70 \%$ \\
\hline Experimental Study & - & - & - & - & 5 & $2.53 \%$ & 3 & $5.55 \%$ \\
\hline $\begin{array}{l}\text { Discourse analysis/ } \\
\text { Text Analysis }\end{array}$ & 2 & $0.99 \%$ & - & - & 4 & $2.03 \%$ & 2 & $3.70 \%$ \\
\hline Panel Data Set & - & - & - & - & - & - & 1 & $1.85 \%$ \\
\hline Film Analysis & - & - & - & - & 1 & $0.50 \%$ & - & - \\
\hline Other & 31 & $15.42 \%$ & 11 & $21.15 \%$ & 45 & $22.84 \%$ & 6 & $11.11 \%$ \\
\hline Mixed Method & 1 & $0.49 \%$ & 3 & $5.76 \%$ & - & - & 1 & $1.85 \%$ \\
\hline $\begin{array}{l}\text { Operational } \\
\text { Research }\end{array}$ & - & - & - & - & 1 & $0.50 \%$ & - & - \\
\hline Survey Model & - & - & - & - & 1 & $0.50 \%$ & - & - \\
\hline Graphical Analysis & - & - & - & - & 1 & $0.50 \%$ & - & - \\
\hline Analysis & 19 & $9.45 \%$ & - & - & 1 & $0.50 \%$ & - & - \\
\hline $\begin{array}{l}\text { Game Theory } \\
\text { (TOPSİS) }\end{array}$ & - & - & - & - & 1 & $0.50 \%$ & - & - \\
\hline $\begin{array}{l}\text { Intermedia/ } \\
\text { Intertextual }\end{array}$ & - & - & - & - & 1 & $0.50 \%$ & - & - \\
\hline Model Design & - & - & - & - & 1 & $0.50 \%$ & - & - \\
\hline Ethnographic & 2 & $0.99 \%$ & - & - & - & - & - & - \\
\hline Total & - & $99.47 \%$ & 52 & $99.97 \%$ & 197 & $99.88 \%$ & 54 & $99.95 \%$ \\
\hline
\end{tabular}

It is observed that the first five research methods and techniques used in master's theses in the public relations field in Turkey are: survey with the ratio of $46.26 \%$, in depth interview with the ratio of $12.93 \%$, content analysis with the ratio of $9.45 \%$, case study with the ratio of $2.98 \%$, comparative and discourse analysis with the ratio of $0.99 \%$. In doctoral theses, the 
first five research methods and techniques used are: survey with the ratio of $53.84 \%$, in-depth interview with the ratio of $7.69 \%$, content analysis with the ratio of $7.69 \%$, mixed method with the ratio of $5.76 \%$, and case analysis with the ratio of $3.84 \%$. The first five research methods and techniques used in master's thesis in the advertising field are: survey with the ratio of $28 \%$, semiotic analysis with the ratio of $19.79 \%$, content analysis with the ratio of $9.13 \%$, in-depth interview with the ratio of $5.07 \%$ and, experimental study with the ratio of $2.53 \%$. It is seen that the research methods and techniques used in public relations and advertising fields are generally in similar sequence.

Table 10: Universities Where Theses Are Published

\begin{tabular}{lcccccccc}
\hline & \multicolumn{3}{c}{ Public Relations } & \multicolumn{5}{c}{ Advertising } \\
\hline University & MA & Percentage & PhD & Percentage & MA & Percentage & PhD & Percentage \\
\hline $\begin{array}{l}\text { Marmara } \\
\text { University }\end{array}$ & 19 & $20.21 \%$ & 11 & $25 \%$ & 30 & $44.11 \%$ & 10 & $33.33 \%$ \\
\hline $\begin{array}{l}\text { Istanbul } \\
\text { Kültür } \\
\text { University }\end{array}$ & - & - & - & - & 12 & $17.64 \%$ & - & - \\
\hline $\begin{array}{l}\text { Gazi } \\
\text { University }\end{array}$ & 21 & $\% 2.34 \%$ & 3 & $6.81 \%$ & 10 & $14.70 \%$ & - & - \\
\hline $\begin{array}{l}\text { Bahçeşehir } \\
\text { University }\end{array}$ & - & - & - & - & 10 & $14.70 \%$ & - & - \\
\hline $\begin{array}{l}\text { Istanbul } \\
\text { University }\end{array}$ & 21 & $22.34 \%$ & 11 & $25 \%$ & - & - & 6 & $20 \%$ \\
\hline $\begin{array}{l}\text { Ege } \\
\text { University }\end{array}$ & - & - & 5 & $11.36 \%$ & 6 & $8.82 \%$ & 6 & $20 \%$ \\
\hline $\begin{array}{l}\text { Selçuk } \\
\text { University }\end{array}$ & 23 & $24.46 \%$ & 14 & $31.81 \%$ & - & - & 4 & $13.33 \%$ \\
\hline $\begin{array}{l}\text { Anadolu } \\
\text { University }\end{array}$ & - & - & - & - & - & - & 4 & $13.33 \%$ \\
\hline $\begin{array}{l}\text { Erciyes } \\
\text { University }\end{array}$ & 10 & $10.63 \%$ & - & - & - & - & - & - \\
\hline \begin{tabular}{l} 
Total \\
\hline
\end{tabular} & 94 & $99.98 \%$ & 44 & $99.98 \%$ & 68 & $99.97 \%$ & 30 & $99.99 \%$ \\
\hline
\end{tabular}

The first five universities where master's theses were published in the field of public relations in Turkey are Selçuk University with the percentage rate of $24.46 \%$, Istanbul University with the percentage rate of $22.34 \%$, Gazi University with the percentage rate of $22.34 \%$, Marmara University with the percentage rate of $20.21 \%$, and Erciyes University with the_percentage rate of $10.63 \%$; in doctoral theses, Selçuk University with the percentage rate of $31.81 \%$, Istanbul University with the percentage rate of $25 \%$, Marmara University with the percentage rate of $25 \%$, Ege University with the percentage rate of $11.36 \%$, and Gazi University with the percentage rate of $6.81 \%$. The top five universities where doctoral theses are published in the field of advertising are in Marmara University with the percentage rate of $33.33 \%$, Istanbul and Ege Universities with the percentage rate of $40 \%$, Selcuk and Anadolu Universities with the percentage rate of $26.66 \%$. It is seen that Marmara University is the university where the master's and doctoral theses are mostly published in the field of advertising. 
Table 11: Theses Programs

\begin{tabular}{|c|c|c|c|c|c|c|c|c|}
\hline \multirow[b]{2}{*}{ Program } & \multicolumn{4}{|c|}{ Public Relations } & \multicolumn{4}{|c|}{ Advertising } \\
\hline & MA & Percentage & PhD & Percentage & MA & Percentage & PhD & Percentage \\
\hline $\begin{array}{l}\text { Art/Art Management/Fine } \\
\text { Arts Education/Painting }\end{array}$ & - & - & - & - & 4 & $2.03 \%$ & - & - \\
\hline Photography & - & - & - & - & 3 & $1.52 \%$ & - & - \\
\hline $\begin{array}{l}\text { Private Law / European } \\
\text { Union Law }\end{array}$ & - & - & - & - & 3 & $1.52 \%$ & 2 & $3.70 \%$ \\
\hline $\begin{array}{l}\text { Production Management } \\
\text { and Marketing }\end{array}$ & 3 & $1.49 \%$ & 1 & $\% 1.92 \%$ & 5 & $2.53 \%$ & 2 & $3.70 \%$ \\
\hline $\begin{array}{l}\text { Management and } \\
\text { Organization }\end{array}$ & 2 & $0.99 \%$ & - & - & - & - & - & - \\
\hline $\begin{array}{l}\text { Marketing / Marketing } \\
\text { Communication }\end{array}$ & 1 & $0.49 \%$ & 1 & $1.92 \%$ & 9 & $4.56 \%$ & 2 & $3.70 \%$ \\
\hline $\begin{array}{l}\text { Advertising / Advertising } \\
\text { and Publicity / Advertising } \\
\text { and Public Relations }\end{array}$ & - & - & - & - & 23 & $11.67 \%$ & 18 & $33.33 \%$ \\
\hline $\begin{array}{l}\text { New Media / Media and } \\
\text { Cultural Studies / Media } \\
\text { and Communication } \\
\text { Systems }\end{array}$ & - & - & - & - & 6 & $3.04 \%$ & - & - \\
\hline Economics / Econometrics & - & - & - & - & 1 & $0.50 \%$ & 1 & $1.85 \%$ \\
\hline $\begin{array}{l}\text { History of Religion / } \\
\text { Sociology of Religion / } \\
\text { Sociology }\end{array}$ & 1 & $0.49 \%$ & - & - & 3 & $1.52 \%$ & & \\
\hline Communication Sciences & 2 & $0.99 \%$ & - & - & 7 & $3.55 \%$ & 1 & $1.85 \%$ \\
\hline $\begin{array}{l}\text { Communication / } \\
\text { Communication Design / } \\
\text { Arts }\end{array}$ & 6 & $2.98 \%$ & 3 & $5.76 \%$ & 21 & $10.65 \%$ & 1 & $1.85 \%$ \\
\hline $\begin{array}{l}\text { Management/ General } \\
\text { Managements / Press } \\
\text { Economics Management }\end{array}$ & 11 & $5.47 \%$ & 1 & $1.92 \%$ & 21 & $10.65 \%$ & 7 & $12.96 \%$ \\
\hline Management Engineering & - & - & - & - & 3 & $1.52 \%$ & & \\
\hline $\begin{array}{l}\text { Business Management/ } \\
\text { Public Administration / } \\
\text { Political Science and Public } \\
\text { Administration }\end{array}$ & 14 & $6.96 \%$ & 2 & $3.84 \%$ & 7 & $3.55 \%$ & 1 & $1.85 \%$ \\
\hline $\begin{array}{l}\text { Graphic/graphic Education/ } \\
\text { Graphic Design/Visual } \\
\text { Communication Design / } \\
\text { Clothing Industry and } \\
\text { Fashion Design }\end{array}$ & - & - & - & - & 20 & $10.15 \%$ & 1 & $1.85 \%$ \\
\hline
\end{tabular}




\section{Table 11 continue}

Public Relations and

Publicity/Public Relations/

$\begin{array}{llllllll}134 & 66.66 \% & 42 & 80.76 \% & 16 & 8.12 \% & 9 & 16.66 \%\end{array}$

Public Relations and

Advertising

Visual Communication

$3 \quad 1.52 \%$

Design / Design

German Language and

Literature / English

language and Literature/

French Language / Arabic

language

\begin{tabular}{lcccccccc}
\hline Turkish Folklore & - & - & - & - & 1 & $0.50 \%$ & & \\
\hline $\begin{array}{l}\text { Radio Television and } \\
\text { Cinema }\end{array}$ & 2 & $0.99 \%$ & - & - & 7 & $3.55 \%$ & 1 & $1.85 \%$ \\
\hline Journalism & 3 & $1.49 \%$ & 1 & 1.92 & 1 & $0.50 \%$ & 1 & $1.85 \%$ \\
\hline Architecture / & - & - & - & & 4 & $2.03 \%$ & 1 & $1.85 \%$
\end{tabular}

Architectural Design /

Interior Architecture and

Environmental Design

\begin{tabular}{lllllllll}
\hline Computer / Industrial & 1 & $0.49 \%$ & - & - & 10 & $5.07 \%$ & 2 & $3.70 \%$
\end{tabular}

Engineering / Industrial

Engineering / Geometric

Engineering / Management

Information Systems /

Media and Communication

Systems / Numerical

Methods / Electronics

Computers

\begin{tabular}{llllllllll}
\hline Translation and Interpreting & - & - & - & & - & & 2 & $1.01 \%$ & -
\end{tabular}

/ Translation Studies

\begin{tabular}{lcccccccc}
\hline Tourism management & 2 & $0.99 \%$ & - & - & 2 & $1.01 \%$ & - & - \\
\hline History & - & - & - & - & 1 & $0.50 \%$ & - & - \\
\hline Strategy & - & - & - & - & 1 & $0.50 \%$ & - & - \\
\hline Turkish Education & - & - & - & - & 1 & $0.50 \%$ & - & - \\
\hline Contemporary Management & - & - & - & - & - & - & 1 & $1.85 \%$ \\
\hline Statistics & - & - & - & - & - & - & 1 & $1.85 \%$ \\
\hline Music Sciences & - & - & - & - & 1 & $0.50 \%$ & 1 & $1.85 \%$ \\
\hline $\begin{array}{l}\text { New Turkish Language } \\
\text { Turkish-Language }\end{array}$ & - & - & - & - & 2 & $1.01 \%$ & - & - \\
Education & & & & & & & & \\
\hline $\begin{array}{l}\text { Interpersonal } \\
\text { Communication }\end{array}$ & - & - & - & - & 1 & $0.50 \%$ & - & - \\
\hline
\end{tabular}


Table 11 continue

\begin{tabular}{lcccccccc}
\hline Sports Management & 1 & $0.49 \%$ & - & - & 1 & $0.50 \%$ & - & - \\
\hline International Economics & - & - & - & - & 1 & $0.50 \%$ & - & - \\
\hline Brand School & - & - & - & - & 1 & $0.50 \%$ & - & - \\
\hline Research Methods & 6 & $2.98 \%$ & 1 & $1.92 \%$ & - & - & - & - \\
\hline Farming Economy & 1 & $0.49 \%$ & - & - & - & - & - & - \\
\hline $\begin{array}{l}\text { Atatürk's Principles } \\
\text { and History of Turkish }\end{array}$ & 1 & $0.49 \%$ & - & - & - & - & - & - \\
Revolution & & & & & & & & \\
\hline Hospital \& Health Facilities & 6 & $2.98 \%$ & & & - & - & - & - \\
\hline Forest engineering & 1 & $0.49 \%$ & & & - & - & - & - \\
\hline Cooperatives & 1 & $0.49 \%$ & - & - & - & - & - & - \\
\hline Office Management & 1 & $0.49 \%$ & - & - & - & - & - & - \\
\hline Cultural Studies & 1 & $0.49 \%$ & - & - & - & - & - & - \\
\hline Labor Economics & 1 & $0.49 \%$ & - & - & - & - & - & - \\
\hline Total & 201 & $99.55 \%$ & 52 & $99.95 \%$ & 197 & $90.67 \%$ & 54 & $99.95 \%$ \\
\hline
\end{tabular}

It is observed that the master's theses published in the public relations field in Turkey are written in programs such as Public Relations with the percentage rate of $66.66 \%$, Business Management, Public Administration, Political Science and Public Administration with the percentage rate of $6.96 \%$, Business Administration, General Business, Communication, Research Methods, Hospital with the percentage rate of $5.47 \%$, and health institutions with the percentage rate of $2.98 \%$. In $\mathrm{PhD}$, it is found that $80.76 \%$ of the theses are about public relations, $5.76 \%$ of them are about communication and $3.84 \%$ of them are about business management.

In the first five Master's theses written in advertising, $11.67 \%$ of them are about business, general business, press economy management, $10.65 \%$ of them are about communication, communication design and communication arts, $10.15 \%$ of them are about public relations, public relations and publicity and $8.12 \%$ of them are about public relations and advertising. In the doctoral theses, first five rank are public relations with the ratio of $33.33 \%, 16,66 \%$ of them are about business, $12.96 \%$ of them are about marketing, $3,70 \%$ of them are about production management and $3.70 \%$ of them are about marketing. 
Table 12: What Is the Publication Density of the Thesis by Years?

\begin{tabular}{|c|c|c|c|c|c|c|c|c|}
\hline & \multicolumn{4}{|c|}{ Public Relations } & \multicolumn{4}{|c|}{ Advertisement } \\
\hline Years & MA & Percentage & PhD & Percentage & MA & Percentage & PhD & Percentage \\
\hline 2017 & 9 & $4.47 \%$ & 2 & $3.84 \%$ & 7 & $3.55 \%$ & 2 & $3.70 \%$ \\
\hline 2016 & 15 & $7.46 \%$ & - & - & 21 & $10.65 \%$ & 3 & $5.55 \%$ \\
\hline 2015 & 19 & $9.45 \%$ & 5 & $9.61 \%$ & 21 & $10.65 \%$ & 4 & $7.40 \%$ \\
\hline 2014 & 25 & $12.43 \%$ & 5 & $9.61 \%$ & 29 & $14.72 \%$ & 7 & $12.96 \%$ \\
\hline 2013 & 12 & $5.97 \%$ & - & - & 22 & $11.16 \%$ & 4 & $7.40 \%$ \\
\hline 2012 & 14 & $6.96 \%$ & - & - & 20 & $10.15 \%$ & 4 & $7.40 \%$ \\
\hline 2011 & 20 & $9.95 \%$ & 6 & $11.53 \%$ & 8 & $4.06 \%$ & 8 & $14.81 \%$ \\
\hline 2010 & 32 & $15.92 \%$ & 4 & $7.69 \%$ & 20 & $10.15 \%$ & 8 & $14.81 \%$ \\
\hline 2009 & 13 & $6.46 \%$ & 2 & $3.84 \%$ & 17 & $8.62 \%$ & 4 & $7.40 \%$ \\
\hline 2008 & 23 & $11.44 \%$ & 10 & $19.23 \%$ & 15 & $7.61 \%$ & 7 & $12.96 \%$ \\
\hline 2007 & 16 & $7.96 \%$ & 7 & $13.46 \%$ & 17 & $8.62 \%$ & 3 & $5.55 \%$ \\
\hline Total & 201 & $98.47 \%$ & 52 & $99.96 \%$ & 197 & $99.94 \%$ & 54 & $99.94 \%$ \\
\hline
\end{tabular}

It is seen that in the field of Public Relations in Turkey, master's theses have the percentage rate of $15.92 \%$, and doctoral theses had the percentage rate of $19.23 \%$ in 2008 and the percentage rate of $7.69 \%$, and doctoral theses were published most in 2008 . The number of graduate theses published in the field of advertising was $14.72 \%$ in 2014 ; these were published in the highest number, the percentage rate of $29.62 \%$ in 2010 and 2011.

Table 13: The Main Subjects of the Theses in the Field of Public Relations

\begin{tabular}{|c|c|c|c|c|}
\hline \multirow[b]{2}{*}{ Subject } & \multicolumn{4}{|c|}{ Public Relations } \\
\hline & MA & Percentage & PhD & Percentage \\
\hline $\begin{array}{l}\text { Public relations (discipline of public relations, } \\
\text { public relations education, public relations studies, } \\
\text { public relations practitioners, public relations units, } \\
\text { political public relations, financial public relations, } \\
\text { situational public relations, public relations } \\
\text { activities, public relations and publicity, press and } \\
\text { public relations, public relations and advertising, } \\
\text { public relations agencies, Public Relations } \\
\text { Association) }\end{array}$ & 186 & $57.76 \%$ & 45 & $45.91 \%$ \\
\hline $\begin{array}{l}\text { Organization, inter- organizational, organizational } \\
\text { activity, non-governmental organization, public, } \\
\text { institution, in-house, lobby }\end{array}$ & 40 & $12.42 \%$ & 12 & $12.24 \%$ \\
\hline $\begin{array}{l}\text { Research, qualitative research, application, } \\
\text { technique, methodology, theory, hypothesis, model } \\
\text { proposal, case study, survey, measurement, analysis, } \\
\text { model proposal }\end{array}$ & 36 & $11.18 \%$ & 18 & $18.36 \%$ \\
\hline
\end{tabular}




\section{Table 13 continue}

\begin{tabular}{lllll}
\hline Business, international business, organization, SME, 32 & $9.93 \%$ & 14 & $14.28 \%$
\end{tabular} establishment, university, hospital, municipality, metropolitan municipality, school

Management, total quality management, local $28 \quad 8.69 \%$ government, public administration, information management, service quality, customer relations management, public relations management, complaint management, corporate reputation management

New communication technology, internet, $99.18 \%$ electronic, digital, social media, new media, virtual media, social networks

\begin{tabular}{lllll}
\hline Total & 322 & $99.98 \%$ & 98 & $99.97 \%$ \\
\hline
\end{tabular}

Figure 1: The Main Subjects of the Theses in the Field of Public Relations

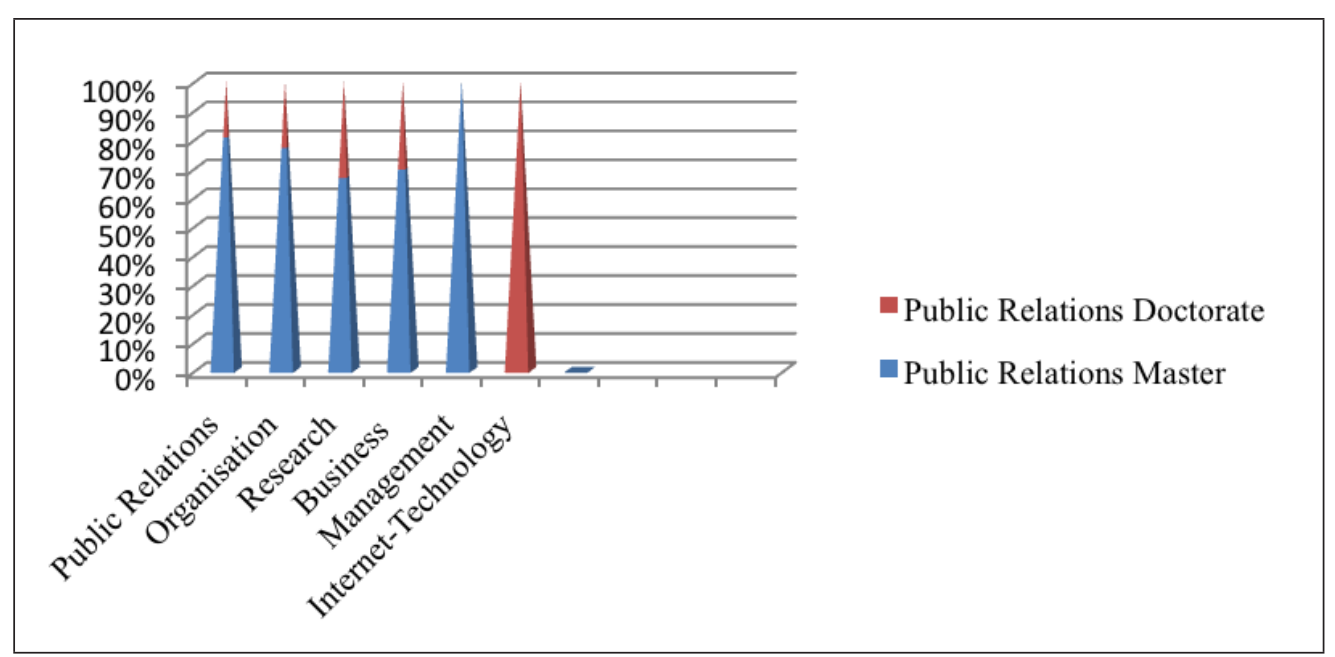

It is observed that $57.76 \%$ of the graduate theses published in the public relations field in Turkey are about public relations and the other concepts related to public relations, $12.42 \%$ of them are about organization and related concepts; $11.18 \%$ of them are about research and related concepts; $9.93 \%$ of them are on business and related concepts; $8.69 \%$ of them are about management and related concepts. On the other hand, it is observed that $45.91 \%$ of the doctoral theses are written in the field of Public Relations on public relations and the other concepts related with public relations; $18.96 \%$ of them are about research and related subjects; $14.28 \%$ of them are about business and related concepts; $12.24 \%$ of them are about organization and related subjects; and $9.18 \%$ of them are about new communication technology and related concepts. 
Table 14: The Main Subject of the Theses in the Field of Advertising

\begin{tabular}{|c|c|c|c|c|}
\hline \multirow[b]{2}{*}{ Subject } & \multicolumn{4}{|c|}{ Advertising } \\
\hline & MA & Percentage & PhD & Percentage \\
\hline $\begin{array}{l}\text { Advertising (open air, viral, written, cinema, banner, } \\
\text { advertising tools, advertising control, advertising } \\
\text { evaluation, advertising policy, advertising directive, } \\
\text { advertising activities, advertising strategies, } \\
\text { advertising translations, advertising campaigns, } \\
\text { advertising films, advertising in advertising, } \\
\text { advertising applications, advertising history, } \\
\text { advertising, interactive advertising, comparative } \\
\text { advertising, advertising, advertising literacy) }\end{array}$ & 172 & $66.15 \%$ & 46 & $63.01 \%$ \\
\hline $\begin{array}{l}\text { Consumption-consumer, consumer, consumer } \\
\text { culture, target audience, consumer behavior }\end{array}$ & 30 & $8.33 \%$ & 5 & $6.84 \%$ \\
\hline Graphic, design, advertising banners & 21 & $8.07 \%$ & - & - \\
\hline Mit & 19 & $7.30 \%$ & - & - \\
\hline Brand, product, goods & 18 & $6.92 \%$ & 5 & $6.84 \%$ \\
\hline Culture / local culture & - & - & 6 & $8.21 \%$ \\
\hline $\begin{array}{l}\text { Marketing, mobile marketing, guerilla marketing, } \\
\text { emotional marketing, neuro marketing, } \\
\text { entertainment marketing, postmodern marketing, } \\
\text { integrated marketing }\end{array}$ & - & - & 6 & $8.21 \%$ \\
\hline Attitude / persuasion & - & - & 5 & $6.84 \%$ \\
\hline Total & 260 & $96.77 \%$ & 73 & $99.94 \%$ \\
\hline
\end{tabular}

Figure 2: The Main Subject of the Theses in the Field of Advertising

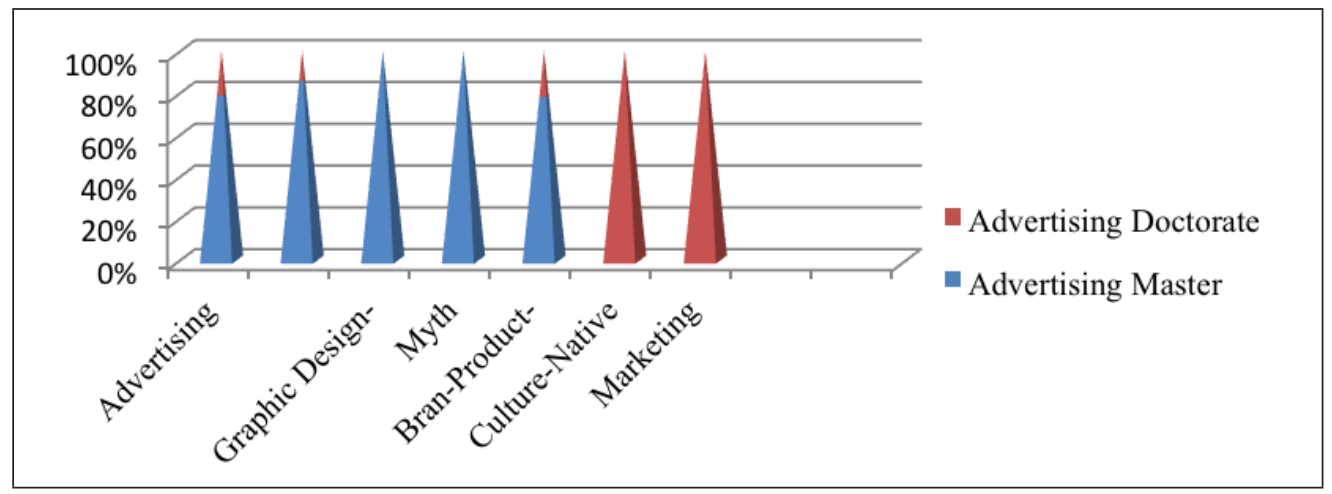

It is seen that $66.16 \%$ of the graduate theses written in the advertising field in Turkey are about advertising and related concepts; $8.33 \%$ of them are about consumption consumer and related concepts; $8.07 \%$ of them are about graphic design considerations; $7.30 \%$ of them are about advertising myths; and $6.92 \%$ of them are about brand, goods and product issues. In 
the doctoral theses written in the advertising field, $63.01 \%$ of them are about advertising and related concepts (ranked first in graduate theses); $8.21 \%$ of them are about culture and local culture subjects; $8.21 \%$ of them are about marketing and related concepts; $6.84 \%$ of them are about consumption consumer concepts; $6.84 \%$ of them are about brand, product, goods and attitudes and persuasion subjects.

\section{Conclusion}

It is highly significant that scientific studies will provide future generations with information and support new studies. Graduate theses are valuable for those who are interested in science and other fields. In this study, a comparative analysis was conducted in the light of the categories determined by general framework on graduate theses in Public Relations and Advertising in Turkey between the years 2007 and 2017. In the light of the data taken from the comparative study, it is possible to tell the following information.

- When types of the theses are examined, it is found that the graduate theses (201 theses) written in the field of public relations in Turkey (2007-2017) are more than the theses written in the field of advertising, and the number of doctoral theses written in the field of advertising (54) are more than those written in the field of public relations (52 theses).

- When the access statuses of the theses are examined, it is determined that the percentage rate of the graduate theses written in public relations and advertising in Turkey is close to each other. When we look at the access status of doctoral theses, it is observed that the public relations are less than the advertising with the percentage rate of $11.06 \%$, advertising is lower than the graduate theses with the ratio of $13.97 \%$. This may be due to the fact that the number of doctoral programs and thus, the number of doctoral theses are less than the graduate theses and the studies differ according to the graduate theses.

- When the language of the theses is examined, it is observed that almost all of the master's and doctoral theses written in public relations are in Turkish. It is also concluded that $80 \%$ of the master's and doctoral theses in advertising are written in Turkish. In the field of advertising, the presence of languages other than Turkish can be related to the characteristics of the field. It is also suggested that the graduate theses are mostly written in Turkish because this is the language of education.

- It is seen that master's theses in public relations and advertising are mostly written by women. Therefore, it is possible to say that women are mostly working on these issues at the master's level. In the doctoral thesis, it is concluded that women mostly write theses in the field of public relations and men mostly write a thesis in the field of advertising. In Turkey, it is possible to express that women have a higher percentage of the theses in the field of public relations. This may be related to the history of public relations and the point of view towards this field.

There are many assumptions about why women are mostly preferred in public relations sector. These assumptions are necessity of positive discrimination, special demands for female sex, females for good presentations, new women politics which presents commercial value, areas which includes flexible hours and fewer sex obstacles, social sex ideology which takes care womens' social ability and it is concluded that public relations give much more opportunities to 
women than other occupations (Aldoory \& Toth, 2002:105). Elmasoğlu (2011:4-5), womens' sharing workforce in public relations was taken into occupation category quoted from statistics of the American Business Departments in the early 1960s. Accordingly, roughly $25 \%$ of the public relations workforce consisted of women. In addition to this, sharing workforce in public relations by women has been gradually risen from 1970 to today. In 1982, women and men were equal in proportion in public relations. From 1985 to 1989 , the ratio of male/female members of the International Business Communicators Association (IABC) was around 40/60. $70 \%$ of IABC members in 1995, and three out of every four members (76\%) in 2002 were women. According to the statistics of the American Department of Business, the proportion of women among total public relations employees was $60 \%$ in 1985, but increased to $68 \%$ in 1993 . According to the latest report published by the American Public Relations Association (PRSA), approximately $70 \%$ of the members are women (Taff, 2003). Additionally, in a study which is called 'A Research on Graduate Public Relations Education in Turkey; Quantitative Content Analysis of the Contribution of PhD theses to Public Relations (2008-2017)', the distribution of the analyzed theses by sexuality was examined. It was determined that $59.17 \%(\mathrm{n}=142)$ of the theses were written by women and $40.83 \%(n=98)$ by men (Solmaz et al., 2018:243). Furthermore, the general average of male students who were placed in the Department of Public Relations and Publicity was 40.26 in 2016, 40.53 in 2017, 43.64 in 2018, and 43.29 in 2019. According to these rates; it is clear that in the distribution of male and female students enrolled in the public relations department, female students are more likely to take part in than male students (https://yokatlas.yok.gov.tr).

- It is observed that the master's theses written in the field of public relations in Turkey are prepared within the range of 101-150 pages. This may be related to general thesis writing rules and related fields. It is also observed that the doctoral theses are prepared within the range of maximum 251-300 pages and in the field of advertising, the theses have 201-250 pages. It is seen that the number of doctoral theses written in the field of Public Relations is higher than those in the field of advertising.

- When the supervisor titles of Master's theses in public relations and advertising programs are examined, it is seen that Assistant Professors are mostly the supervisors. This may be related to the opening conditions of Master's programs and the hierarchy in education. $55.26 \%$ of the doctoral theses written in the field of public relations and $75.92 \%$ of the theses in the field of advertising are supervised by Professors. This case may also be related to the academic hierarchy.

- When the research methods of the theses in the fields of public relations and advertising are examined, it is seen that the survey, which has/makes use of the most quantitative data collection technique, is used in the theses. This suggests that there may be a tendency towards quantitative techniques in these fields. However, it is possible to say that different methods and techniques are used as it is seen that qualitative techniques are also used.

- It is found that Public Relations and Publicity/Public Relations/Public Relations and Advertising programs are the most widely published programs in master's and doctoral theses. In the field of advertising, it is found that both in master's and doctoral theses, advertising, advertising and publicity, advertising and public relations programs are the most productive programs. In this respect, it is possible to say that the fields are studied by different disciplines but most of the theses are carried out in the main programs. 
- The most published master's and doctoral theses in the advertising field are published at Marmara University; Selçuk University has published the most Master's and doctoral theses in public relations field. This may be related to the program history of the universities, the number of faculty members, and the quota of the program.

- It is observed that most of the master's theses in the field of public relations were published in 2010, and most of the doctoral theses were published in 2008. In the field of advertising, most of the master's theses were written in 2014 and most of the doctoral theses were written in 2014 and 2008. In the field of public relations, there was an increase in the number of theses in 2008 and 2010 and in the field of advertising in 2014.

- It is found that the theses written in the fields of public relations and public relations concept, and advertising and advertising concept have the highest percentage rate in master's and doctoral degrees.

- It is seen that the main subjects of theses in the fields of public relations are public relations, organizations, research, business, management, internet-technology. The main subjects of theses in the fields of advertising are advertising, consumption-consumer, graphic designadvertising banner, myth, brand-product-goods, culture-local culture, marketing.

In addition to the results mentioned above, a comparative study can be carried out with the theses outside Turkey in the new studies related to these fields. Thus, a great contribution can be provided to new theses by comparing international and national similarities and differences.

\section{References}

Aldoory, L. \& Toth, E. (2002). Gender discrepancies in a gendered profession: A developing theory for public relations. Journal of Public Relations Research, 14(2), 103-126.

Akgün, S. (2015). Karl Popper'in tarih, toplum ve siyaset felsefesi üzerine görüşleri. Felsefe Dergisi, (7), 59-76.

Aziz, A. (2008). Sosyal bilimlerde araştırma yöntemleri ve teknikleri. Ankara: Nobel Akademik Yayıncilik.

Batu, M. \& Ayaz, Y.Y.(2018). Bilimsel araştırmalarda sosyal medya ile ilgili 'yeniyi’ bulmak: Lisansüstü tezlerine yönelik bir inceleme. Akdeniz İletişim Dergisi, 29, Özel Say1, 284-301.

Becan, C. (2019). Reklamcılık literatüründe egemen ve eleştirel yaklaşımlara yönelik karşılaştırmalı bir alan çalışması: Lisansüstü tezler ve makaleler üzerine bibliyometrik bir analiz. Bilecik Şeyh Edebali Üniversitesi Sosyal Bilimler Enstitüsü Dergisi, 4(1), 314-334.

Benligiray, S. (2012). Araştırmacıların bankacılık alanına bilimsel katkıları: Bankacılık konusunda yapılan lisansüstü tezlere ilişkin bir araştırma. Süleyman Demirel Üniversitesi Vizyoner Dergisi, $3(6), 26-46$.

Bilgin, N. (2014). Sosyal bilimlerde içerik analizi: Teknikler ve örnek çalışmalar. 3. Baskı, Ankara: Siyasal Kitabevi.

Çetin, M., Yaşın, C. \& Sönmez, B. (2016). Türkiye'de halkla ilişkiler alanındaki doktora tezleri üzerinden alanda yapılan çalışmaların değerlendirilmesi. İletişim Kuram ve Araştırma Dergisi, 43, 242-264.

Çıvgın, A. G. (2013). David Hume: Felsefe ve metafiziğin mahiyeti. Kaygı Dergisi, 20, 31-40.

Çilingir, A. (2017). İletişim alanında içerik analizi yöntemi kullanılarak yapılan yüksek lisans doktora tezleri üzerine bir inceleme. Erciyes İletişim Dergisi, 5(1), 148-160. 
Doğan, O. (2017). Türkiye'de veri madenciliği konusunda yapılan lisansüstü tezler üzerine bir araştırma. Gazi Üniversitesi İktisadi ve İdari Bilimler Fakültesi Dergisi, 19(3), 929-951.

Elmasoğlu, K. (2015). Halkla ilişkiler alanında cinsiyet ayrımcılığına ilişkin öğrencilerin tutumları. KTÜ İletişim Araştırmaları Dergisi, 9, 1-20.

Okay, A. \& Okay. A. (2008). Undergraduate and graduate public relations education in Turkey: A quantitative study of dissertations contributions to public relations field (1984-2007). Selçuk İletişim Dergisi, 5(2), 5-14.

Polat, H. (2020). Halkla ilişkiler alanındaki doktora tezlerinde yeni medya olgusu: Nitel bir veri analizi. Uluslararası Anadolu Sosyal Bilimler Dergisi, 4(4), 289-306.

Solmaz, B., Ergen, Y. \& Alkan, Ö. (2018). Türkiye'de lisansüstü halkla ilişkiler eğitimi üzerine bir araştırma: Doktora tezlerinin halkla ilişkiler alanına katkısının niceliksel içerik analizi (20082017). Selçuk Üniversitesi Sosyal Bilimler Enstitüsü Dergisi, 39, 236-248.

Şimşek, A., Özdamar, N., Becit, G., Kılıçer, K., Akbulut, Y.\& Yıldırım, Y. (2008). Türkiye'deki eğitim teknolojisi araştırmalarında güncel eğilimler. Selçuk Üniversitesi Sosyal Bilimler Dergisi, 1(9), 439-458.

Taff, H. P. (2003). Times have changed? IABC research foundation's the velvet ghetto "study revisited". Retrieved December 28, 2019, from http://users.manchester.edu/FacStaff/MPLahman/ Homepage/McCombsMywebsite/velvetghettoarticle.pdf

Uçak, N. (2009). Bilimsel iletişimin zamana ve disiplinlere göre değişimi: Tezler üzerine bibliyometrik bir inceleme. Project Number: 107K505, Ankara.

Uçak, N. Ö. \& Al, U. (2009). Bilimsel iletişimin zamana göre değişimi: Bir atıf analizi çalışması. Bilgi Dünyas1, 10(1), 1-22.

Yaşın, C., Çetin, M. \& Sönmez, B. (2017). Halkla ilişkiler alanındaki doktora tezleri üzerinden Türkiye ve ABD’de bilimsel bilginin gelişiminin analizi. Selçuk İletişim Dergisi, 10(1), 454-480.

Yıldırım, A. \& Şimşek, H. (2011). Sosyal bilimlerde nitel araştırma yöntemleri, ( $8^{\text {th }}$ edition). Ankara: Seçkin Yayıncılık.

Yükseköğretim Program Atlası (YÖK Atlas) (2019), Halkla ilişkiler ve tanıtım programı bulunan tüm üniversiteler. Retrieved December 28, 2019, from https://yokatlas.yok.gov.tr/lisans-bolum. php?b=10087 